\title{
ANALYSIS OF LIFELONG LEARNING IN INDUSTRIAL ENTERPRISES IN THE BORDER REGIONS OF THE SLOVAK REPUBLIC AND THE CZECH REPUBLIC
}

\author{
Jana MESÁROŠOVÁ ${ }^{1}$, Mária BEHÚLOVÁ ${ }^{2}$, Alena PAULIKOVÁ ${ }^{1}$ \\ ${ }^{1,2}$ SLOVAK UNIVERSITY OF TECHNOLOGY IN BRATISLAVA \\ FACULTY OF MATERIALS SCIENCE AND TECHNOLOGY IN TRNAVA \\ ${ }^{1}$ INSTITUTE OF INDUSTRIAL ENGINEERING AND MANAGEMENT \\ ${ }^{2}$ INSTITUTE OF APPLIED INFORMATICS, AUTOMATION AND MECHATRONICS \\ Ulica JÁna Bottu 2781/25, 91724 TRNAVA. SlOVAK REPUBliC \\ e-mail: jana.mesarosova@stuba.sk,maria.behulova@stuba.sk, alena.paulikova@stuba.sk \\ Received 30 August 2021, Accepted 21 October 2021, Published 24 November2021
}

\begin{abstract}
Lifelong learning is a conscious learning process with the aim of acquiring knowledge, skills and competences throughout an individual's life. For lifelong learning to be successful, learning activities must meet market requirements. Correct skills of employees and a serious approach to lifelong learning are now being viewed as essential meet the skills and workforce needs of the future. Well-adjusted education system improves quality of life and sense of selfesteem of employees, besides it brings benefits of competitiveness for the whole company. The key goal of the article was to identify the current needs of lifelong learning in industrial enterprises in technical fields. The conducted questionnaire survey was focused on the companies in the border regions of the Slovak Republic (the Trnava, Trenčin and Žilina regions) and the Czech Republic (the South Moravian, Zlin and Moravian-Silesian regions). The research was aimed primarily at the companies in the machinery and automotive industries. Based on the results of the questionnaire, the requirements for the training focused on technical areas such as: materials engineering, mechanical engineering, computer aided design and production preparation, automation and control of technological processes and mechatronic systems, production quality, IT security and others were defined.
\end{abstract}

\section{Keywords}

Lifelong learning, Machinery industry, Automotive industry

\section{INTRODUCTION}

Demographic development of natural population growth in the Central and Western European countries is characterized by a relatively elderly population structure [1-3]. Professional life of employees in industrial enterprises is prolonged, which is due to aging of 
the population. This situation is addressed by the concept of age management, eight basic pillars of which are as follows [4]:

1. Knowledge of age issue.

2. Accommodating attitude towards aging.

3. Management that understands individuality and differences.

4. Quality and functional measures of age management.

5. Ensuring good work ability and motivation.

6. High level of competencies.

7. Quality of work organization.

8. Life Satisfaction.

The above-mentioned pillars include also lifelong learning, which focuses on the development of knowledge, abilities, skills and competences of employees in industrial enterprises [5]. There are several definitions of the term of lifelong learning in the professional literature sources. Within the literature review, we present selected definitions:

- Lifelong learning - are all activities that take place during life in order to improve knowledge, skills and abilities. Lifelong learning as a basic principle of education and training applied in the educational system of the Slovak Republic, which consists of a) school education and b) further education following the level of education achieved in school education [6].

- Lifelong learning is a continuous process, present in all cultures, societies and religions. The provision of lifelong learning opportunities over the entire life span is a sine qua non if communities, individuals and organizations are to be able to handle and make effective use of knowledge, skills, values and capacities and also to contribute to their creation and transformation [7].

- Lifelong learning is the development of human potential through a continuously supportive process which stimulates and empowers individuals to acquire all the knowledge, values, skills, and understanding they will require throughout their lifetimes and to apply them with confidence, creativity and enjoyment in all roles, circumstances, and environments [8,9].

Lifelong education is important in many ways. It helps to improve employee engagement and increases employee retention. If done correctly, it also has positive impact on efficiency, innovation and productivity $[10,11]$. The results indicate directions and possibilities how to increase the quality of education, innovation of content, forms and methods of lifelong learning of employees in the machinery and automotive industries.

\section{MATERIALS AND METHODOLOGY OF EXPERIMENT}

A questionnaire survey was carried out in order to analyse needs in the field of lifelong learning in industrial enterprises in the border regions of the Slovak Republic (the Trnava, Trenčín and Žilina regions) and the Czech Republic (the South Moravian, Zlín and MoravianSilesian regions) [12].

The key goal of the analysis was to map actual needs of lifelong learning in industrial enterprises in the machinery and automotive industries. Analysis was oriented particularly on the technical areas, which are usually absent in lifelong learning, namely:

- Materials engineering and production quality assurance;

- Production technologies, including computer-aided production preparation;

- Automation and control of technological processes and mechatronic systems.

Transfer of university knowledge to enterprises also plays a very important role in skills development [13]. The questionnaire survey was conducted in the cooperation with the 
OpusConsulting, Ltd. Company [14] in the period from November to December 2020. The online questionnaire platform of SURVIO was used for the analysis to ensure the maximum possible return rate, even with regard to the emergency situation related to the COVID-19 pandemic.

Individual interviews were also part of the survey in order to complete the on-line ones and to obtain more details about content, forms and place of training. Each interview took 45 minutes minimum.

The questionnaire survey was completed by 30 respondents from the Czech Republic and more than 40 from the Slovak Republic. They work for various categories of enterprises ranging from the micro, small and medium-sized up to the large enterprises with more than 250 employees. The analysis of attained results are provided in the following section of the article.

\section{ATTAINED RESULTS}

\section{Results of the questionnaire survey in the Slovak Republic}

Most companies that participated in the questionnaire survey are active in the field of automotive industry or machinery industry. The survey was attended mainly by the large companies with more than 250 employees, located in the Trenčín, Trnava and Žilina Regions. The survey showed that the average age of employees in the analysed companies ranged from 40 to 50 years, and most companies have a minimum representation of specialists among their employees. Most surveyed companies are in a stabilized phase and strategically plan to develop mainly their product innovation or the production process. The analysed companies train their employees with the aim to increase the company's potential and to ensure the development of employees' skills and abilities. Employee training is financially demanding for the companies, and there is not high interest among the employees. Nevertheless, training of employees does take place in the companies, and is also registered in almost all the companies surveyed.

The questionnaire survey showed that companies train their employees in the areas suitable for their job position and classification, and choose the appropriate way of training for individual groups of workers.

The survey focused on three target groups present in each company: Group 1 - operators, Group 2 - technical and service staff and Group 3 - technical and economic managers/ engineers or so called "mental staff". Questions and responses were then evaluated according to individual aspects. The reactions of the respondents showed that all target groups were educated, but the difference was in the place of training, methods and focus of specific education. Conventional training is suitable for Group 1 and Group 2. There are several other methods of education convenient for the target Group 2. Self-education and self-development are the most suitable for the target Group 3.

On-site company training is recommended for the target Groups 1 and 2. A suitable type of training for technical engineers and economic managers involves conferences and education in training centers outside the company. There was a demand from the companies for training of improving employee's qualifications for all target groups. All target groups have completed training in quality, safety, soft skills and other specific skills, so far. The most educated group comprised mental employees (Group 3) (76\%), followed by the target Groups 1 (29\%) and $2(26 \%)$.

\section{Results of a questionnaire survey in the Czech Republic}

The survey within the companies addressed in the Czech Republic mapped the structure of employees, the state and vision of the companies, while focusing, however, on their portfolio and possible requirements for employee training. 
Most of the companies participating in the investigation are active in the automotive or machinery industries. The representation of enterprises with regard to the number of employees was quite balanced; the survey was attended by large enterprises as well as medium-sized, small and micro enterprises. The survey showed that the average age of employees in the analysed companies was between 30 and 50 years, and most companies have a certain percentage of specialists in their employees (approximately $10 \div 20 \%$ ).

Most of the surveyed companies are in a good phase of the company life and strategically plan development and innovation in several directions. Education in the companies is governed by their needs, possibilities and focus. The companies train their employees not only to increase prosperity of the company, but mainly to retain their own employees and to increase their qualifications and experience. Employee training is financially demanding, and there is not much interest in training on the part of employees. Nevertheless, training of employees takes place in companies, it is mostly recorded and planned. The questionnaire survey showed that companies train their employees in the areas suitable for their job positions and classification, and choose appropriate training methods for individual groups of workers.

The questionnaire survey covered as well as three main target groups. The reactions of the respondents showed that all target groups are educated, but there is a difference in the training venue, methods and focus. For the target Group 1 and partly also for the target Group 2, education in the form of on-site training is more appropriate. Target Group 2 and especially target Group 3 prefer education outside the company using more sophisticated methods, such as coaching or self-development. However, all target groups completed training in quality, safety, soft skills and other specific skills. The most frequently trained groups were mental employees $(60 \%)$ and technical and service staff $(47 \%)$. Target Group 1, i. e. operators, were trained in a minimum number of the companies surveyed $(7 \%)$.

\section{Results of a supplementary questionnaire survey in the Czech Republic and the Slovak Republic}

Besides the above-mentioned questionnaire, individual interviews were conducted as a supplementary survey in the selected companies from Slovakia and the Czech Republic, which showed interest in the lifelong learning of their employees. The objective of the supplementary survey was to complement the results of the online questionnaire survey, and to specify the interest of individual business entities in lifelong learning in terms of its focus, content, scope, forms and methods of education.

As can be seen in Figure 1, the companies preferred the trainings in the areas closest to their focus, and particularly those which would develop those employees' skills that could be really used for the benefit of the company.

All companies acknowledged the possibility of choosing training in a given area, while simultaneously selecting a specific target group. For most companies, education of their employees is important, and it is the right choice of specific training for a specific target group that ensures meaningfulness, orderliness and, consequently, benefits for society as a whole. All companies assume connections between individual target groups, their mutual cooperation and possible transition of the employees having completed the training from one group to another within the company hierarchy. These processes presuppose continuous, systematic and simultaneous training of all target groups. Figure 2 shows that companies are most interested in training technicians and economic managers (53\%), while they are the least willing to provide lifelong learning to a group of operators (13\%). 


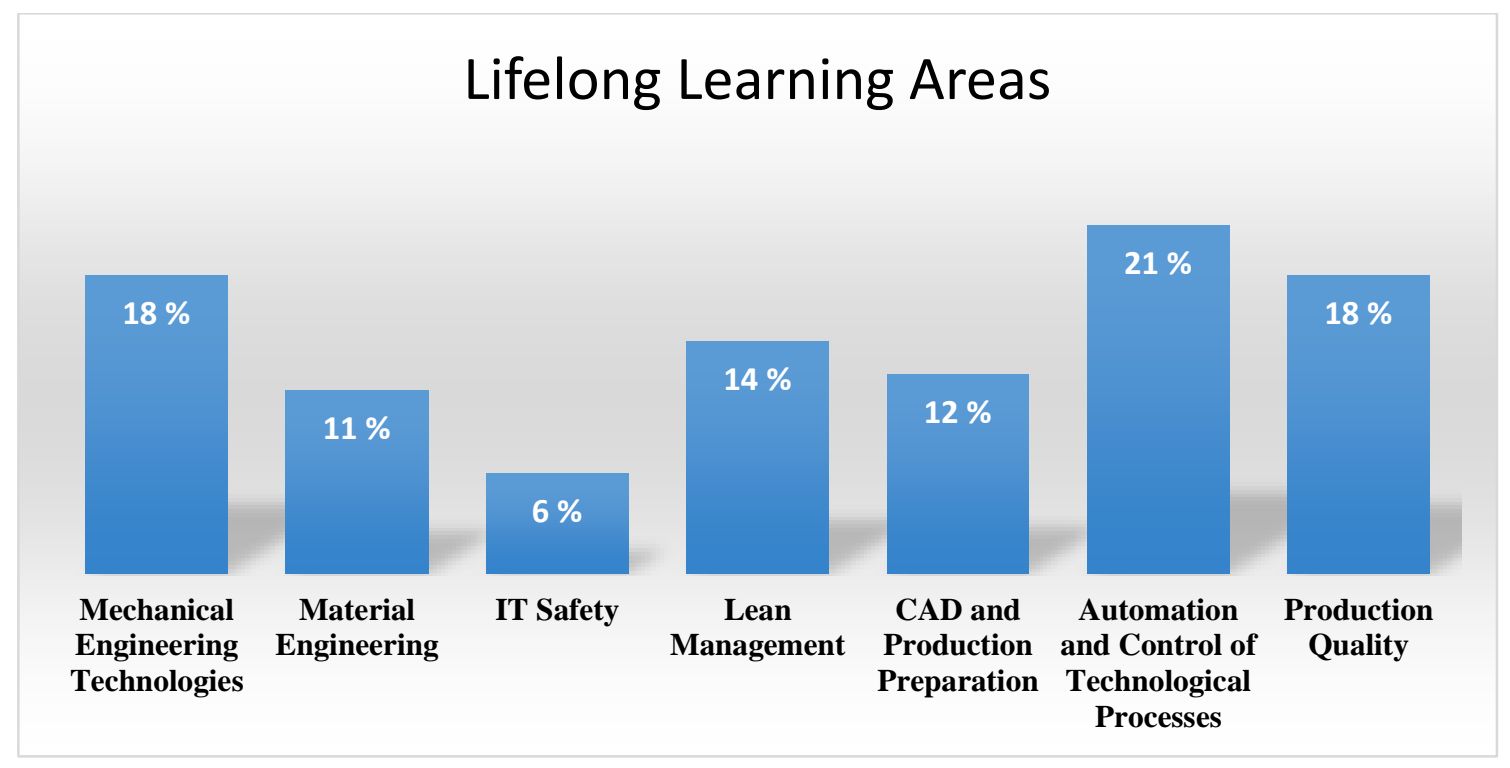

Fig. 1 Selection of areas of lifelong learning

In addition to defining the scope (short-term or long-term) of education, companies had the opportunity to choose the method of education that would suit them best. They can select forms of continuous education, as well as frequency, i. e. number of days per week, the number of weeks, months or even years. The methods of education offered a wide range of options: onsite training directly in the company or external one, face to face or online, in the morning or evening. The preferences of companies differ significantly, so it is not possible to recommend a specific training option in the form - training area, target group, duration and method of education. Figure 3 compares the suitability of training in terms of their duration. Sixty percent of companies prefer only short-term training.

When evaluating the results of the supplementary questionnaire, it should be taken into account that the respondents were under the pressure of the COVID19 pandemic for almost a year at the time of its implementation. Due to the pandemic situation and government restrictions, companies were forced to look for new operational solutions, learn and apply novel methods of management, development, communication and the overall operation of the company.

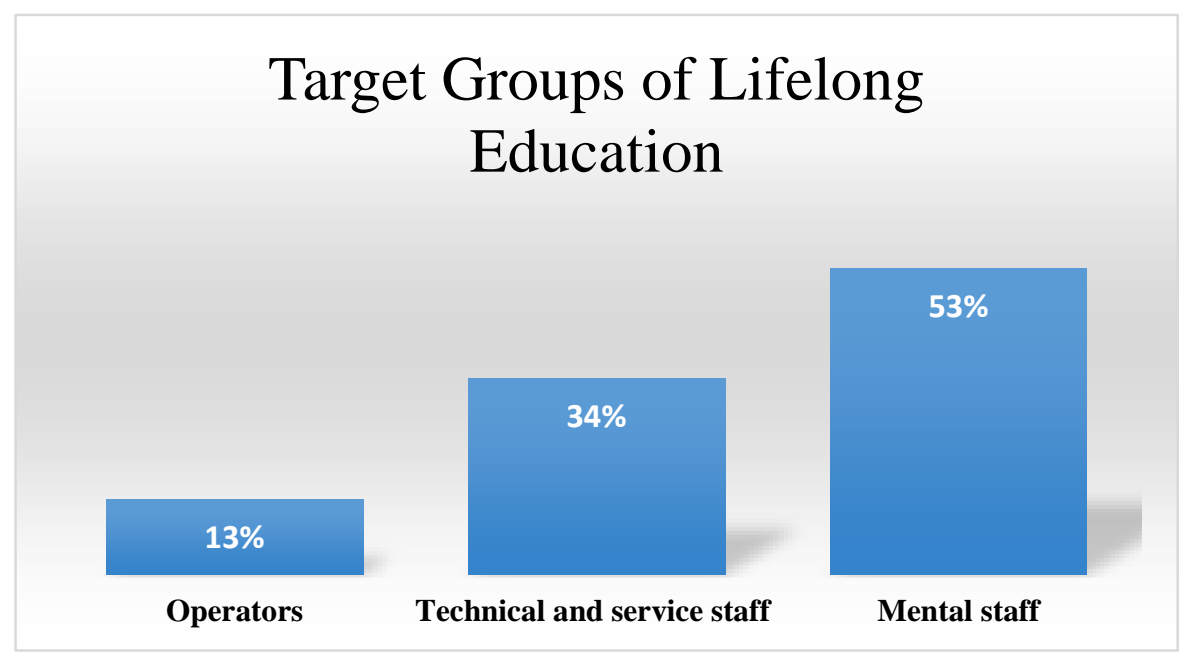

Fig. 2 Suitability of lifelong learning for target groups of employees 


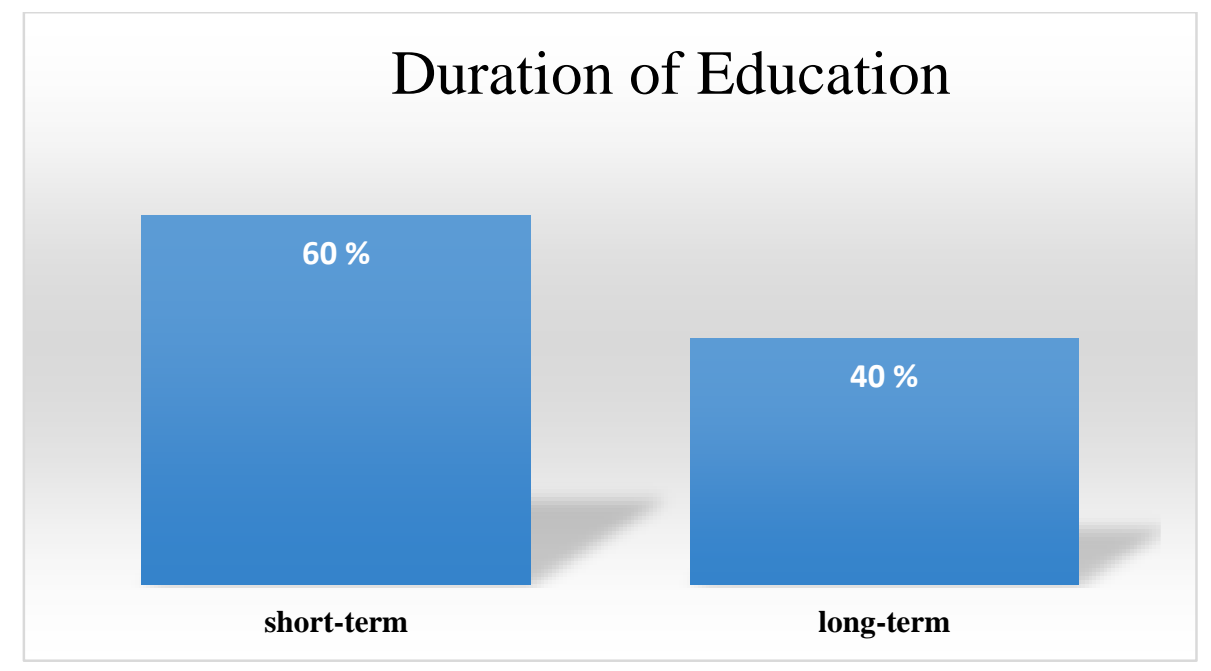

Fig. 3 Comparison of training duration

\section{DISCUSSION}

The companies in the Slovak and Czech Republics involved to questionnaire survey are aware of the importance of lifelong learning for their employees, as well as recognize the impact of the provided education on the overall prosperity of the company. Most companies educate their employees according to their abilities, keep related records, and realize what kind of training makes sense for individual groups of employees. The questionnaire survey was conducted in both countries in the same way, and the questionnaires as well as the method of questioning were identical.

Specific facts could be identified from the comparison of the participating companies in both countries:

- The professional orientation of companies in both countries was similar; the companies were mainly operating in the automotive industry or mechanical engineering.

- In terms of the number of employees, all types of enterprises were quasi-equally involved in the questionnaire survey in the Czech Republic, while large enterprises predominated in the Slovak Republic. In the Slovak Republic, no star-up was participated in the survey.

- Participating companies in the Czech Republic reported the average age of their employees $30 \div 40$ years (50\% of companies), $40 \div 50$ years (40\% of companies). The average age of employees in the Slovak Republic was obviously higher, since the companies declared the average age of their employees $40 \div 50$ years (66\% of companies) and $30 \div 40$ years ( $29 \%$ of companies).

- Proportion of specialists with higher education within the companies in the Czech Republic is generally higher than that in the Slovak Republic. in the Czech Republic is Republic is generally higher than that in the Slovak Republic. Twenty percent of companies in the Czech Republic employ $6 \div 10 \%$ of highly specialized employees and $33 \%$ of companies even have $11 \div 20 \%$ of specialists. In the Slovak Republic, $40 \%$ of the companies have only $1 \div 5 \%$ of specialists.

- Employees' training takes place in the companies in both countries. In the Slovak Republic, it turned out that a larger number of the surveyed companies keep records of education. All surveyed companies in both countries are strategically planning development mainly in the field of innovation. The addressed companies in the Czech 
Republic were in relatively higher stages of the company life (57\% expansion, $30 \%$ stabilization) compared to the Slovak Republic (26\% expansion, $42 \%$ stabilization). In the Slovak Republic, companies in the stabilized phase predominated, while in the Czech Republic, they were mostly in the growth phase.

- In both countries, the survey focused on the above-mentioned three target groups of employees. In the Czech Republic, the target Group 2 and especially the target Group 3 $(67 \%)$ are trained. In the Slovak Republic, all three groups are educated, however, Group 3 takes part in lifelong learning more often (76\%). As it follows from attained results, companies in both countries place emphasis on the education of the Group 3, which requires the application of more sophisticated training methods and forms that usually take place outside the company. Lifelong learning not only brings the development of employee competencies, but also contributes to the growth of the company's potential.

- In both countries, high financial costs are considered by companies to be a major barrier to lifelong learning.

Based on the implemented questionnaire survey, the requirements for the training of employees in the automotive and engineering industries in the following fields were defined:

A) in the area of materials engineering

- mechanical testing of materials

- non-destructive testing of materials

- study of the material structures

- measuring of the physical properties of materials

- plastic materials

B) in the area of mechanical engineering technologies

- surface treatment

- welding

- forming and heat treatment

- machining

- injection molding

C) in the area of computer-aided design and production preparation

- CNC programming

- CAD systems

- modeling and simulation of mechanical systems using the FEM

- modeling and simulation of technological processes

D) in the area of automation, control of technological processes and mechatronic systems

- robotization, technical devices of automated control

- artificial intelligence, neural networks, computer learning

- programming of regulation and manipulation devices

- PLC programming

- hydraulic and pneumatic systems

- data acquisition and processing

- reliability and safety of technical systems

E) in the area of quality assurance

- QMS and EMS in automotive industry

- IMS for quality assurance

- metrology 
F) in the area of Lean Management

- OEE - Overall Equipment Efficiency

- Deming Cycle (PDCA cycle)

- Lean management tools and methods

G) in the area of IT security

- IT security - area of prevention, detection and correction

- personal data security

- introductory training of employees

$\mathrm{H})$ in the area of soft skills

- team-work

- stress management

- communication and presentation skills

\section{CONCLUSIONS}

The companies contacted in the survey in the Czech Republic and the Slovak Republic are aware of the importance of lifelong learning for their employees, as well as the impact of provided training on the prosperity of the company.

Most companies provide training for their employees according to their capabilities, keep records of training and identify training activities that are necessary (e. g. due to legislative requirements) or important for the company in order to ensure company's operation and development.

Based on the evaluation of the labour market and trends in lifelong learning at the national level in the Slovak Republic and the Czech Republic, as well as within the EU, it the necessary to pay attention to educational activities in the areas of ICT skills, particularly a combination of soft and hard ICT skills along with multi-field technical skills.

It is also important to set the parameters of the education quality evaluation system, which will enable continuous improvement of the level of educational activities. In order to increase the interest in lifelong learning among employees of industrial enterprises, it is necessary to create a system of recognition of qualifications that will help employees in their career growth.

\section{Acknowledgement}

The contribution was prepared within the project Establishment of strategic partnerships and preparation of advanced life-long learning courses for companies and clusters with innovative potential in the field of mechanical engineering and automotive industry (EDU-MaTech), financed from the Operational Program 304000 INTERREG V-A Slovak Republic - Czech Republic 2014-2020. Application code: NFP304010U768.
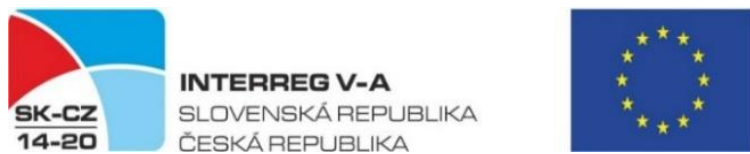

EURÓPSKA ÚNIA

EURÓPSKY FOND

REGIONÁLNEHO ROZVOJA

SPOLOČNE BEZ HRANÍC 


\section{References}

[1] ČAMBÁL, M., URBANOVIČOVÁ, P., MIKULÁŠKOVÁ, J. 2017. Koexistencia rôznych generácí́ zamestnancov - výzva pre súčasné priemyselné podniky (The coexistence of different generations of employees - a challenge for today's industrial). Fórum manažéra (Forum of Manager), 2, 8-14. ISSN 1339-9403.

[2] LESTHAEGHE, R. 2020. The second demographic transition, 1986-2020: sub-replacement fertility and rising cohabitation-a global update. Genus, 76, 10. ISSN 166987.

[3] HESS, M. 2017. Rising Preferred Retirement Age in Europe: Are Europe's Future Pensioners Adapting to Pension System Reforms? Journal of Aging \& Social Policy, 29(3), 245-261. ISSN 08959420.

[4] HORVÁTHOVÁ, P., BLÁHA, J., ČOPÍKOVÁ, A. 2016. Řizení lidských zdrojů - nové trendy (Human resource management - new trends). Prague: Management Press, 2016, 428 p. ISBN 97880-7261-430-1.

[5] VRAŇAKOVÁ, N., GYURÁK BABELOVÁ, Z., CHLPEKOVÁ, A. 2021. Sustainable Human Resource Management and Generational Diversity: The Importance of the Age Management Pillars. Sustainability, 13(15), 8496. ISSN 2071-1050.

[6] www.zakonypreludi.sk, Zákon o celoživotnom vzdelávaní a o zmene a doplnení niektorých zákonov (Act on Lifelong Learning and on Amendments to Certain Acts). [Online]. [Accessed: 102021] Available at https://www.zakonypreludi.sk/zz/2009-568.

[7] OUANE, A. 2008. The Routledge International Handbook of Lifelong Learning: UNESCO's drive for lifelong learning. $1^{\text {st }}$ ed. London: Routledge, 2008. 560 p. eBook ISBN 9780203870549.

[8] LONGWORTH, N., DAVIES, W. K. 1996. Lifelong Learning: New Vision, New Implications, New Roles for People, Organizations, Nations and Communities in the $21^{\text {st }}$ Century. London: Kogan, 1996.,179 p. ISBN-0-7494-1972-5.

[9] CHOVANCOVÁ, J. RUSKO, M. 2021. Environmentálne správanie malých a stredných podnikov na Slovensku (Environmental performance of the small and medium-sized enterprises in Slovakia). In: Manažérstvo životného prostredia (Environmental management). $1^{\text {st }}$ Edition. Žilina. Slovak Republic: Strix, n.f., 2010. ISBN 978-80-89281-67-1, pp. 35-39.

[10] VOZIČKA, V. 2008. Strategie celoživotniho učeni ČR (Lifelong learning strategy of the Czech Republic). Prague: TAURIS Publishing House, 2008. 97 p. ISBN 978-80-254-2218-2.

[11] KALOUS, J., VESELÝ, A. 2006. Vybrané problémy vzdělávaci politiky (Selected problems of educational policy). Prague: Karolinum, 2006. 160 p. ISBN: 80-246-1262-3.

[12] www.survio.com, Questionnaire [Online]. [Accessed: 10-2021] Available at https://www.survio.com/survey/d/Q1W9U4Q9K5W1K7K3A?preview=1

[13] VADKERTIOVÁ, A., NOVÁKOVÁ, R., OVSENÁK, V. 2015. Transfer univerzitných poznatkov do malých a stredných podnikov (Transfer of university knowledge to small and medium-sized enterprises). $1^{\text {st }}$ Edition. London: Science Publishing, 118 p. ISBN 978-0-9928772-4-8.

[14] https://opusconsulting.cz/en/ [Online]. [Accessed: 10-2021]

\section{ORCID}

Jana Mesárošová

Mária Behúlová

Alena Pauliková
0000-0002-3822-2309

0000-0002-8125-8366

0000-0002-2959-5656 